\title{
Perilaku Wanita Pekerja Seks Melakukan Konseling dan Tes HIV
}

\author{
Ruwayda $^{1}$, M.Dody Izhar ${ }^{2}$ \\ Dosen Poltekkes Jambi Jurusan Kebidanan ${ }^{1}$ \\ Dosen Fakultas Kesehatan Masyarakat Universitas Jambi ${ }^{2}$
}

\begin{abstract}
The high prevalence of current HIV / AIDS problems is not only a health problem of infectious disease, but has become a very widespread public health problem, one of the high risk groups is Female Sex Workers (WPS). The number of female sex workers who counsel and test HIV in Rawasari Health Center is still low that is 27,67\%. This research is quantitative research with cross sectional method, using Systematic Random Sampling technique with sample number 77 female sex worker. Instrument used questionnaire, analyzed by univariate analysis, bivariate and chi-square test. The result of the analysis of 77 respondents, $61 \%$ have bad behavior to do counseling of HIV test and 39\% have good behavior do counseling of HIV test, 57,1\% of respondents have low knowledge, 50,6\% of respondents have unfavorable attitude and 50,6 respondents argue that the role of health workers is good for HIV counseling and testing. The result of bivariate analysis shows that there is significant correlation between knowledge ( $p$-value $=0,000)$, attitude ( $p$-value $=0,000)$ and the role of health officer ( $p$-value $=0,013)$ with female sex worker conduct HIV counseling and testing at Payo Sigadung City of Jambi.

It is hoped that health officers at Rawasari Puskesmas will improve direct and periodic counseling through information media, encourage and encourage female sex workers to conduct HIV counseling and testing.
\end{abstract}

Keywords: Knowledge, attitude, role of health officer, counseling and HIV test

\section{PENDAHULUAN}

Di zaman yang semakin berkembang ini terdapat banyak sekali penyakit. Ada penyakit menular dan ada pula yang tidak menular. Diantaranya adalah penyakit menular melalui hubungan seksual yang biasa disebut IMS (Infeksi Menular Seksual). Hubungan seksual tidak terbatas pada genito - genital, oro - genital, tetapi juga ano - genital. Banyak jenis yang bisa digolongkan sebagai penyakit IMS sesuai dengan mikro organisma penyebabnya seperti Jamur (Candida albican), Parasit (Trichomonas vaginalis), Bakteri (Neisseria gonorhoea, Chlamydia trachomatis, Treponema pallidum atau sifilis, Bakterial vaginosis, Hemophylus ducreii atau Ulkus mole), Virus (Herpes simplex atau Herpes genitalis, Human papilloma virus atau Kondiloma akuminata, HIV dan AIDS) (Depkes RI, 2006).

Menurut perkiraan UNAIDS (United Nations Programme on Hiv-AIDS) di dunia ini setiap hari terdapat lebih dari 5.000 orang pengidap baru HIV dan AIDS yang berusia antara 15-24 tahun, hampir 1800 orang yang hidup dengan HIV positif di bawah usia 15 tahun tertular dari ibunya, serta sekitar 1.400 orang anak dibawah usia 15 tahun meninggal akibat mengalami fase AIDS. Hingga saat ini HIV-AIDS masih merupakan salah satu masalah kesehatan masyarakat utama di Indonesia. Sejak pertama kali ditemukan (1987) sampai dengan tahun 2011, kasus HIV-AIDS tersebar di 368 (73,9\%) dari 498 kabupaten/kota di seluruh (33) provinsi di Indonesia. Propinsi pertama kali ditemukan adanya kasus HIV-AIDS adalah Provinsi Bali (1987), sedangkan yang terakhir melaporkan adanya kasus HIV (2011) adalah Provinsi Sulawesi Barat (Kemenkes RI, 2012).

Sesuai dengan tujuan pengendalian HIVAIDS yaitu menurunkan angka kesakitan dan kematian dan diskriminasi serta meningkatkan kualitas ODHA, maka diperlukan upaya pengendalian serta layanan HIV-AIDS dan IMS yang komprehensif di seluruh kabupaten/kota tertular di Indonesia. Pengendalian yang komprehensif meliputi upaya promotif, preventif, kuratif dan rehabilitatif dan melibatkan sektor terkait, baik pemerintah maupun swasta dan masyarakat (kader, LSM, kelompok dampingan sebaya, ODHA, keluarga, PKK, tokoh adat, tokoh agama dan tokoh masyarakat). (Kemenkes RI, 2012). 
Tingginya prevalensi masalah HIV/AIDS saat ini bukan hanya masalah kesehatan dari penyakit menular semata, tetapi sudah menjadi masalah kesehatan masyarakat yang sangat luas. Penanganan tidak hanya dari segi medis tetapi juga dari psikososial dengan berdasarkan pendekatan kesehatan masyarakat melalui upaya pencegahan primer, sekunder, dan tertier. Salah satu upaya tersebut adalah deteksi dini untuk mengetahui status seseorang sudah terinfeksi HIV/AIDS atau belum melalui konseling dan testing HIV/AIDS sukarela, bukan dipaksa atau diwajibkan (Nursalam \& Kurniawati, 2011).

Human Immunodeficiency Virus (HIV) disebabkan oleh virus yang disebut HIV, yaitu sejenis virus yang ada di dalam darah manusia yang dapat melemahkan daya tahan tubuh, sehingga pengidapnya mudah terserang infeksi lain, seperti tuberkulosis, sariawan dan diare yang berkepanjangan. Disamping itu, HIV juga ditemukan dalam jumlah yang sangat sedikit di dalam air mata, air liur, cairan otak, dan keringat. Namun sampai sekarang belum ada bukti-bukti bahwa HIV dapat ditularkan melalui cairancairan tersebut. Seseorang mengidap HIV hanya dapat diketahui apabila dilakukan pemeriksaan darah di layanan konseling dan tes HIV, yang meliputi KTS=Konseling dan tes HIV secara Sukarela dan KTIP=Konseling dan Tes HIV yang diprakarsai Petugas Kesehatan (Kemenkes RI, 2012).

Layanan konseling dan test HIV merupakan pintu gerbang ke semua akses layanan kesehatan yang diperlukan, termasuk pencegahan penularan. Begitu diagnosis ditegakan, maka akses terapi dapat dimulai, karena itu ART harus tersedia di Rumah Sakit rujukan tingkat propinsi dan kabupaten//kota. Layanan konseling dan tes HIV sebagai strategi kesehatan masyarakat juga merupakan komponen utama dalam program HIV yang bertujuan untuk mengubah perilaku berisiko dan memberikan informasi tentang pencegahan HIV (Kemenkes RI, 2012).

Salah satu kelompok risiko tinggi adalah Wanita Pekerja Seks (WPS). Estimasi WPS di Indonesia pada tahun 2010 diperikirakan mencapai $0,30 \%$ dari populasi perempuan dewasa (15-49 tahun). Kelompok WPS sangat rentan tertular HIV akibat hubungan seks dan perilaku seks yang tidak aman (KPA, 2011).
Akibat pekerjaannya, seorang pekerja seks sangat beresiko terkena penyakit menular melalui hubungan seks, termasuk HIV/AIDS, dibanding perempuan-perempuan lain. Bila ia sudah terkena gonorhea, chlamydia, herpes, atau sifilis resiko tertular HIV makin besar. Terutama bagi pekerja seks yang masih remaja. Virus HIV dengan mudah menyelinap masuk lewat luka di vagina, padahal organ seksual remaja belum berkembang sepenuhnya sehingga gampang terluka saat berhubungan seks. Banyak pekerja seks tidak mendapat informasi yang memadai tentang semua resiko diatas, lebih-lebih tentang cara pencegahan dan penanggulangannya. Lantaran prasangka masyarakat, mereka tersisih dan terkucil, tidak dianggap sebagai anggota masyarakat yang memiliki hak atas informasi demi menjaga kesehatan. Bahkan banyak pekerja seks yang tidak dilayani, atau dilayani sembarangan saja, bila berobat ke Puskesmas atau dokter (Burns,et.al, 2005).

Kurangnya pengetahuan tentang
HIV/AIDS akan mengakibatkan
ketidaksanggupan bagi WPS menghadapi hasil test, maka dari itu perlu diberikan konseling untuk meningkatkan pengetahuan klien. Salah satu cara untuk meningkatkan pengetahuan seseorang dengan memberikan konseling. Sebagai tenaga kesehatan perawat mempunyai peran yang sangat penting dalam memelihara dan meningkatkan kesejahteraan kesehatan masyarakat. Dengan demikian, peran perawat sebagai pendidik sangat berperan dalam usaha meningkatkan pengetahuan klien dengan konseling (Efendi, 2008).

Pengetahuan yang kurang juga berdampak pada sikap WPS yang kurang. Masih banyak WPS yang belum menyadari bahwa mereka termasuk sebagai kelompok risiko tinggi. Hal ini membuat WPS tidak sadar bahwa mereka sangat rentan untuk terkena HIV/AIDS sehingga masih banyak yang memiliki sikap yang kurang karena masih banyak WPS yang mau melayani pelanggan yang tidak menggunakan kondom ataupun yang menolak menggunakan, banyak WPS yang berpendapat bahwa WPS yang sehat tidak perlu melakukan konseling dan pemeriksaan VCT (Efendi, 2008).

Salah satu peran perawat sebagai pendidik dalam keperawatan. Perawat berperan dalam mendidik individu, keluarga, kelompok, dan masyarakat serta tenaga kesehatan yang 
berada di bawah tanggung jawabnya. Peran ini berupa penyuluhan kepada klien, maupun bentuk desiminasi ilmu kepada peserta didik keperawatan (Potter \& Perry, 2005).

Berdasarkan hasil penelitian terhadap pasien HIV/AIDS di UPIPI RSU Dr. Soetomo yang dilakukan oleh Patola L.N.(2005) dalam Nursalam \& Kurniawati (2011) di ketahui bahwa
VCT efektif dalam mengubah pengetahuan, sikap dan tindakan pasien berisiko tinggi untuk melakukan tes HIV dimana $100 \%$ responden penelitiannya bersedia melakukan tes HIV setelah diberikan konseling

Berikut data yang diperoleh di Provinsi Jambi dari Tahun 2011-2013 adalah:

Tabel 1. Perkembangan Situasi HIV/AIDS menurut Kab/Kota Di Provinsi Jambi

Tahun 2011- 2013

\begin{tabular}{clcccccccc}
\hline \multirow{2}{*}{ NO } & \multirow{2}{*}{ KAB/KOTA } & \multicolumn{2}{c}{2011} & \multicolumn{2}{c}{2012} & \multicolumn{2}{c}{2013} & \multicolumn{2}{c}{ JUMLAH } \\
& & HIV & AIDS & HIV & AIDS & HIV & AIDS & HIV & AIDS \\
\hline 1. & KOTA JAMBI & $\mathbf{2 4}$ & $\mathbf{3 4}$ & $\mathbf{8 5}$ & $\mathbf{4 2}$ & $\mathbf{9 5}$ & $\mathbf{6 6}$ & $\mathbf{2 0 4}$ & $\mathbf{1 4 2}$ \\
2. & BATANG HARI & 1 & 2 & 3 & 2 & 8 & 6 & 12 & 10 \\
3. & MUARO JAMBI & 3 & 6 & 9 & 2 & 5 & 6 & 17 & 14 \\
4 & BUNGO & 5 & 1 & 7 & 2 & 2 & 1 & 14 & 4 \\
5. & TEBO & 1 & 0 & 0 & 0 & 3 & 2 & 4 & 2 \\
6. & MERANGIN & 0 & 0 & 1 & 2 & 3 & 0 & 4 & 2 \\
7. & SAROLANGUN & 1 & 0 & 0 & 0 & 1 & 1 & 2 & 1 \\
8. & KERINCI & 1 & 1 & 3 & 1 & 1 & 0 & 5 & 2 \\
9. & SUNGAI PENUH & 0 & 0 & 0 & 0 & 1 & 0 & 1 & 0 \\
10. & TANJAB BARAT & 10 & 4 & 20 & 5 & 16 & 7 & 46 & 16 \\
11. & TANJAB TIMUR & 2 & 1 & 0 & 2 & 2 & 1 & 4 & 4 \\
& JUMLAH & 48 & 49 & 122 & 58 & 136 & 90 & 333 & 197 \\
\hline
\end{tabular}

Sumber: Data Dinas Kesehatan Provinsi Jambi.

Berdasarkan tabel diatas terlihat Perkembangan Situasi HIV/AIDS di Kab/Kota di Provinsi Jambi yang terbanyak adalah Kota Jambi kasus HIV sebesar 204 kasus dan AIDS sebesar 142 kasus.

Dinas Kesehatan Propinsi Jambi, mendirikan klinik IMS di tiga Kabupaten yaitu Kabupaten Muaro Bungo, Kabupaten Tanjung Jabung Barat dan Kota Jambi. Berdasarkan SK Kementerian Kesehatan Republik Indonesia No 1285/Menkes/SK/ X/2002 tentang Pedoman Penanggulangan Penyakit IMS dan HIV/AIDS, Dinas Kesehatan Propinsi Jambi menunjuk Puskesmas Rawasari untuk melaksanakan program klinik IMS yang diberi nama "Mitra Berseri”. Latar belakang didirikannya klinik IMS di Puskesmas Rawasari Kota Jambi adalah karena terdapatnya lokalisasi "Payo Sigadung", sebagai jalur lintas Sumatera, serta banyaknya kelompok risiko tinggi. Dan adanya komitmen dari petugas kesehatan untuk menanggulangi penyebaran HIV/AIDS. Puskesmas telah memberikan layanan IMS sejak Agustus 2011 dan layanan konseling dan tes HIV sejak Desember 2012 baik itu layanan di dalam gedung maupun di luar gedung (mobile) (Puskesmas Rawasari Kota Jambi, 2012).

Layanan konseling dan tes HIV pada kelompok risiko yang berkunjung di klinik VCT "Mitra Berseri' Puskesmas Rawasari Kota Jambi adalah sebagai berikut:

Tabel 2. Kunjungan pada Kelompok Risiko Tahun 2013

\begin{tabular}{clcc}
\hline No & \multicolumn{1}{c}{ Kunjungan pada Kelompok Risiko } & Jumlah & Persentase \\
\hline 1 & Wanita Pekerja Seks & $\mathbf{1 4 8}$ & $\mathbf{3 5 , 8 4}$ \\
2 & Pria Pekerja Seks & 26 & 6,29 \\
3 & Waria & 14 & 3,38 \\
4 & Lelaki Seks Lelaki & 31 & 7,53 \\
5 & Pasangan resiko tinggi & 55 & 13,32 \\
6 & Pelanggan Pekerja Seks & 54 & 13,27 \\
7 & Lain-lain & 84 & 20,37 \\
& Jumlah & 413 & 100 \\
\hline
\end{tabular}

Sumber : Data Klinik VCT “Mitra Berseri” Puskesmas Rawasari, 2013. 
Dari tabel diatas terlihat jumlah kunjungan pada kelompok risiko yang terbanyak adalah Wanita Pekerja Seks sebesar 148 orang $(35,84 \%)$. Jumlah WPS yang berada di Payo Sigadung Kota Jambi yang melakukan konseling dan tes HIV di Klinik VCT "Mitra Berseri" tahun 2013 sebagai berikut:

Tabel 3. Kunjungan WPS di Klinik VCT Mitra Berseri Puskesmas Rawasari

\begin{tabular}{clcc}
\hline \multicolumn{4}{c}{ Berseri Puskesmas Rawasari } \\
No & Bulan & Jumlah \\
& & & $\begin{array}{c}\text { Positif } \\
\text { HIV }\end{array}$ \\
\hline 1 & Januari & 0 & 0 \\
2 & Februari & 13 & 0 \\
3 & Maret & 11 & 1 \\
4 & April & 20 & 0 \\
5 & Mei & 12 & 1 \\
6 & Juni & 14 & 0 \\
7 & Juli & 9 & 0 \\
8 & Agustus & 2 & 0 \\
9 & September & 8 & 1 \\
10 & Oktober & 6 & 0 \\
11 & November & 5 & 0 \\
12 & Desember & 6 & 0 \\
& Jumlah & 106 & 3 \\
\hline
\end{tabular}

WPS yang berada di Lokalisasi Payosigadung Kota Jambi yang melakukan konseling dan tes HIV yaitu sebanyak 106 orang dan yang positif HIV sebanyak 3 orang. Data Ketua RT 05 Kelurahan Rawasari yang merupakan tempat Payo Sigadung diketahui tahun 2013 jumlah WPS sebanyak 383 orang, maka jumlah WPS yang melakukan konseling dan tes HIV masih rendah yaitu sebanyak 106 orang (27,67\%).

\section{Bahan dan Cara}

Jenis penelitian yang digunakan adalah penelitian kuantitatif dengan menggunakan rancangan studi cross sectional. Lokasi penelitian ini dilaksanakan di Payosigadung Wilayah Kerja Puskesmas Rawasari Kota Jambi.
Populasi dalam penelitian ini adalah seluruh wanita pekerja seks yang berada di wilayah kerja Puskesmas Rawasari yaitu Lokalisasi Payosigadung Kota Jambi yang berjumlah 383 orang.

Berdasarkan hasil perhitungan dengan menggunakan rumus Lameshow (1997) maka besar sampel sebanyak 77 responden, menggunakan teknik Systematic random sampling dimana caranya adalah membagi jumlah sampel atau anggota populasi dengan perkiraan jumlah sampel yang diinginkan, hasilnya adalah interval sampel. Sampel diambil dengan membuat daftar elemen atau nomor rumah secara acak antara 1 sampai dengan banyaknya rumah. Kemudian membagi dengan jumlah sampel yang diinginkan, hasilnya sebagai interval adalah $\mathrm{X}$, maka yang terkena sampel adalah setiap kelipatan dari $\mathrm{X}$ tersebut di Wilayah Kerja Puskesmas Rawasari yaitu Lokalisasi Payosigadung Kota Jambi. N (jumlah populasi) sebanyak 179 rumah, $\mathrm{n}$ (sampel) 77 orang dan I (intervalnya) 179: 77 =2,3 Maka rumah yang terkena sampel adalah elemen (nomor rumah) yang mempunyai nomor kelipatan 2, no. 1, 3, 5, 7, dan seterusnya sampai mencapai jumlah 77 anggota sampel.

HASIL DAN PEMBAHASAN

Tabel 4. Distribusi Frekuensi Umur Wanita Pekerja Seks Melakukan Konseling dan Tes HIV di Payo Sigadung Kota Jambi

\begin{tabular}{cccc}
\hline No & Umur & Frekuensi & $\begin{array}{c}\text { Persentase } \\
(\boldsymbol{\%})\end{array}$ \\
\hline 1 & $>30$ tahun & 36 & 46,8 \\
2 & < 30 tahun & 41 & 53,2 \\
& Jumlah & 77 & 100 \\
\hline
\end{tabular}

Tabel 4 menunjukkan bahwa sebagian besar responden berumur $<30$ tahun sebanyak 41 responden $(53,2 \%)$.

Tabel 5. Distribusi Frekuensi Responden Berdasarkan Perilaku Wanita Pekerja Seks Melakukan Konseling dan Tes HIV di Payo Sigadung Kota Jambi

\begin{tabular}{ccccc}
\hline \multirow{2}{*}{ No } & Perilaku Wanita Pekerja Seks Melakukan & Jumlah & Persentase (\%) \\
& & Konseling dan Tes HIV & 47 & 61,0 \\
1. & Kurang baik & & 30 & 39,0 \\
2. & Baik & \multirow{2}{*}{ Jumlah } & 77 & 100 \\
\hline
\end{tabular}

Berdasarkan tabel 5 diketahui bahwa dari

77 responden, sebanyak $61 \%$ memilki perilaku 
kurang baik melakukan konseling tes HIV dan sebanyak 39\% memiliki perilaku baik melakukan konseling tes HIV.

Hasil penelitian diketahui dari 14 pertanyaan yang diberikan kepada responden, terdapat beberapa pertanyaan dalam kuesioner yang dijawab salah dan benar. Untuk lebih jelasnya dapat dilihat tabel berikut:

\section{Tabel 6. Pengetahuan Wanita Pekerja Seks Melakukan Konseling dan Tes HIV di Payo Sigadung Kota Jambi}

\begin{tabular}{|c|c|c|c|}
\hline \multirow{2}{*}{ No } & \multirow{2}{*}{ Pengetahuan } & \multicolumn{2}{|c|}{$\begin{array}{l}\text { Distribusi } \\
\text { Salah }\end{array}$} \\
\hline & & $\mathbf{F}$ & $\%$ \\
\hline 1 & Menurut saudari apakah yang dimaksud dengan konseling dan tes HIV? & 27 & 35,1 \\
\hline 2 & Menurut saudari apakah tujuan melakukan konseling dan tes HIV? & 27 & 35,1 \\
\hline 3 & $\begin{array}{l}\text { Menurut saudari apakah tujuan melakukan konseling dan tes HIV dalam hal } \\
\text { pencegahan penularan HIV? }\end{array}$ & 21 & 27,3 \\
\hline 4 & Menurut saudari mengapa perlu melakukan konseling dan tes HIV sukarela? & 46 & 59,7 \\
\hline 5 & Menurut saudari apakah manfaat melakukan konseling dan tes HIV? & 44 & 57,1 \\
\hline 6 & $\begin{array}{l}\text { Menurut saudari tujuan kegiatan konseling bagi anda adalah untuk membantu agar } \\
\text { dapat? }\end{array}$ & 58 & 75,3 \\
\hline 7 & Menurut saudari siapa yang menjadi sasaran untuk melakukan konseling dan tes HIV? & 22 & 28,6 \\
\hline 8 & Menurut saudari sasaran konseling dan tes HIV bagi kelompok berisiko adalah? & 36 & 46,8 \\
\hline 9 & Menurut saudari prinsip pelayanan konseling dan tes HIV adalah? & 41 & 53,2 \\
\hline 10 & Menurut saudari kapan jadwal melakukan konseling dan tes HIV? & 27 & 35,1 \\
\hline 11 & Menurut saudari ada berapa tahapan konseling dan tes HIV? & 14 & 18,2 \\
\hline 12 & Menurut saudari materi yang didapatkan saat konseling sebelum tes HIV adalah? & 45 & 58,4 \\
\hline 13 & Selain sukarela apa lagi yang menjadi prinsip dalam konseling dan tes HIV? & 41 & 53,2 \\
\hline 14 & Menurut saudari apakah yang dimaksud dengan tes HIV? & 44 & 57,1 \\
\hline
\end{tabular}

Berdasarkan tabel 6 menggambarkan bahwa dari 77 responden sebanyak 58 responden $(75,3 \%)$ tidak mengetahui tujuan kegiatan konseling bagi klien, sebanyak 46 responden $(59,7 \%)$ tidak mengetahui manfaat melakukan konseling dan tes HIV dan sebanyak 45 responden $(58,4 \%)$ tidak mengetahui materi yang didapat saat konseling sebelum melakukan tes HIV.

Dari penghitungan jumlah jawaban maka peneliti dapat mengetahui berapa frekuensi responden yang memiliki pengetahuan yang rendah dan pengetahuan yang tinggi. Setelah dilakukan scoring 14 pernyataan pada variabel pengetahuan dengan nilai mean/median, maka responden dengan pengetahuan yang rendah jika score atau nilai jawaban < median (8) dari nilai total, dan responden dengan pengetahuan yang tinggi jika skor atau nilai jawaban $\geq$ median (8) dari nilai total. Untuk lebih jelasnya dapat dilihat tabel berikut:
Tabel 7. Distribusi Frekuensi Responden Berdasarkan Pengetahuan Wanita Pekerja Seks Melakukan Konseling dan Tes HIV di Payo Sigadung Kota Jambi

\begin{tabular}{clcc}
\hline No & Pengetahuan & Jumlah & $\begin{array}{c}\text { Persentase } \\
(\%)\end{array}$ \\
\hline 1. & Rendah & 44 & 57,1 \\
2. & Tinggi & 33 & 42,9 \\
& Jumlah & 77 & 100 \\
\hline
\end{tabular}

Berdasarkan tabel 7 dapat diketahui dari 77 responden, sebanyak 44 responden $(57,1 \%)$ mempunyai pengetahuan yang rendah terhadap konseling dan tes HIV dan sebanyak 33 responden $(42,9 \%)$ mempunyai pengetahuan yang tinggi terhadap konseling dan tes HIV.

Hasil penelitian diketahui dari 14 pernyataan yang diberikan kepada responden, terdapat beberapa pertanyaan dalam kuesioner yan dijawab sangat setuju, setuju, tidak setuju dan sangat tidak setuju. Untuk lebih jelasnya dapat dilihat tabel berikut: 
Tabel 8. Gambaran Sikap Wanita Pekerja Seks Melakukan Konseling dan Tes HIV di Payosigadung Kota Jambi

\begin{tabular}{|c|c|c|c|c|c|c|c|c|c|c|}
\hline \multirow{3}{*}{ No } & \multirow{3}{*}{ Sikap } & \multicolumn{9}{|c|}{ Distribusi } \\
\hline & & \multicolumn{2}{|c|}{ SS } & \multicolumn{2}{|c|}{$\mathbf{S}$} & \multicolumn{2}{|c|}{ TS } & \multicolumn{2}{|c|}{ STS } & \multirow{2}{*}{ Total } \\
\hline & & $\mathbf{F}$ & $\sum$ & $\mathbf{F}$ & $\sum$ & $\mathbf{F}$ & $\sum$ & $\mathbf{F}$ & $\sum$ & \\
\hline 1 & $\begin{array}{l}\text { Saya akan melakukan konseling untuk mendapatkan } \\
\text { informasi penyakit HIV/AIDS }\end{array}$ & 37 & 148 & 40 & 120 & 0 & 0 & 0 & 0 & 268 \\
\hline 2 & $\begin{array}{l}\text { Saya akan melakukan konseling dan tes HIV rutin walaupun } \\
\text { tes HIV negatif sesuai dengan petunjuk petugas kesehatan }\end{array}$ & 57 & 228 & 20 & 60 & 0 & 0 & 0 & 0 & 288 \\
\hline 3 & $\begin{array}{l}\text { Saya akan terbuka kepada petugas kesehatan mengenai } \\
\text { kondisi saya saat konseling }\end{array}$ & 23 & 92 & 17 & 51 & 37 & 74 & 0 & 0 & 217 \\
\hline 4 & $\begin{array}{l}\text { Saya akan melakukan konseling untuk mengetahui cara } \\
\text { menghindari penyakit HIV/AIDS }\end{array}$ & 31 & 124 & 31 & 93 & 15 & 30 & 0 & 0 & 247 \\
\hline 5 & $\begin{array}{l}\text { Saya akan melakukan konseling untuk meluruskan } \\
\text { pemahaman yang salah tentang HIV/AIDS dan mitosnya }\end{array}$ & 36 & 144 & 17 & 51 & 24 & 48 & 0 & 0 & 243 \\
\hline 6 & $\begin{array}{l}\text { Saya akan melakukan konseling untuk mengetahui cara } \\
\text { pencegahan penularan HIV }\end{array}$ & 55 & 220 & 22 & 66 & 0 & 0 & 0 & 0 & 286 \\
\hline 7 & $\begin{array}{l}\text { Saya akan melakukan konseling untuk mengetahui cara } \\
\text { mencegah diri dari penularan infeksi penyakit yang lain dan } \\
\text { penularan kepada orang lain }\end{array}$ & 37 & 148 & 25 & 75 & 15 & 30 & 0 & 0 & 253 \\
\hline 8 & $\begin{array}{l}\text { Saya tidak mau melakukan konseling dan tes HIV takut } \\
\text { ketahuan penyakit }\end{array}$ & 25 & 25 & 52 & 104 & 0 & 0 & 0 & 0 & 129 \\
\hline 9 & $\begin{array}{l}\text { Saya tidak perlu mengetahui hal-hal yang berkaitan dengan } \\
\text { HIV dan AIDS karena merasa tidak memiliki perilaku yang } \\
\text { berisiko tertular HIV dan AIDS. }\end{array}$ & 48 & 48 & 29 & 58 & 0 & 0 & 0 & 0 & 106 \\
\hline 10 & $\begin{array}{l}\text { Saya tidak perlu melakukan tes HIV kembali } \\
\text { karena hasil tes HIV saya negative }\end{array}$ & 25 & 25 & 52 & 104 & 0 & 0 & 0 & 0 & 129 \\
\hline 11 & $\begin{array}{l}\text { Saya tidak perlu melakukan konseling dan tes HIV karena } \\
\text { saya belum ada gejala AIDS }\end{array}$ & 43 & 43 & 33 & 66 & 1 & 3 & 0 & 0 & 112 \\
\hline 12 & $\begin{array}{l}\text { Saya akan melakukan konseling sesuai dengan tahapan } \\
\text { yang dianjurkan petugas kesehatan }\end{array}$ & 55 & 220 & 22 & 66 & 0 & 0 & 0 & 0 & 286 \\
\hline 13 & $\begin{array}{l}\text { Saya akan menganjurkan pasangan saya untuk melakukan } \\
\text { konseling dan tes HIV juga }\end{array}$ & 48 & 192 & 29 & 87 & 0 & 0 & 0 & 0 & 279 \\
\hline 14 & $\begin{array}{l}\text { Saya tidak mau melakukan konseling dan tes HIV takut } \\
\text { waktu diambil darah }\end{array}$ & 28 & 28 & 34 & 68 & 15 & 45 & 0 & 0 & 141 \\
\hline
\end{tabular}

Berdasarkan tabel 8 dari 14 pernyataan, pernyataan dengan nilai rendah adalah yang menyatakan tidak perlu mengetahui hal-hal yang berkaitan dengan HIV dan AIDS karena merasa tidak memiliki perilaku yang beresiko tertular HIV dan AIDS yaitu 106, tidak perlu melakukan konseling dan tes HIV karena belum ada gejala AIDS yaitu 112, dan tidak mau melakukan konseling dan tes HIV takut ketahuan penyakit yaitu 129.

Dari penghitungan jumlah jawaban maka peneliti dapat mengetahui berapa frekuensi responden yang memiliki sikap yang kurang baik dan baik. Setelah dilakukan scoring 14 pernyataan pada variabel sikap dengan nilai mean/median maka responden dengan sikap kurang baik jika score atau nilai jawaban < median (48) dari nilai total, dan responden dengan sikap baik jika skor atau nilai jawaban $\geq$ median (48) dari nilai total. Untuk lebih jelasnya dapat dilihat tabel berikut:

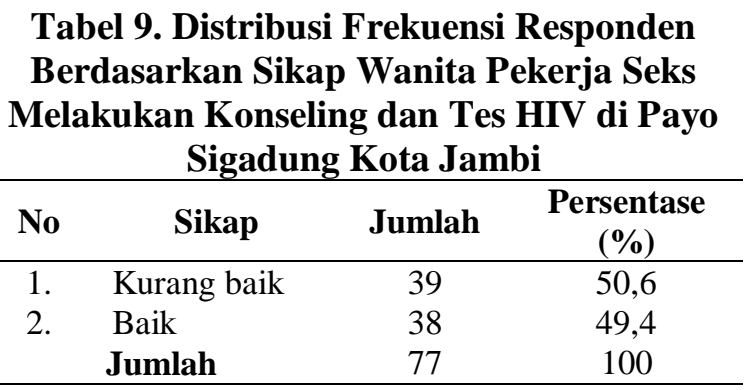

Berdasarkan tabel 9 dapat diketahui bahwa dari 77 responden, sebanyak 39 responden $(50,6 \%)$ mempunyai sikap yang kurang baik terhadap konseling dan tes HIV dan sebanyak 38 
responden $(49,4 \%)$ mempunyai sikap yang baik terhadap konseling dan tes HIV.

Tabel 10. Peran Petugas Kesehatan dengan Perilaku Wanita Pekerja Seks Melakukan konseling dan Tes HIV di Payo Sigadung Kota Jambi

\begin{tabular}{|c|c|c|c|c|c|c|c|c|c|c|}
\hline \multirow{3}{*}{ No } & \multirow{3}{*}{ Peran Petugas Kesehatan } & \multicolumn{9}{|c|}{ Distribusi } \\
\hline & & \multicolumn{2}{|c|}{$\mathbf{S}$} & \multicolumn{2}{|c|}{ SR } & \multicolumn{2}{|c|}{ JR } & \multicolumn{2}{|c|}{ TP } & \multirow{2}{*}{ Total } \\
\hline & & $\mathbf{F}$ & $\sum$ & $\mathbf{F}$ & $\sum$ & $\mathbf{F}$ & $\sum$ & & $\sum$ & \\
\hline 1 & $\begin{array}{l}\text { Apakah petugas kesehatan Puskesmas Rawasari menjelaskan } \\
\text { tentang faktor risiko penyebab HIV/AIDS? }\end{array}$ & 27 & 108 & 28 & 84 & 18 & 36 & 4 & 4 & 232 \\
\hline 2 & $\begin{array}{l}\text { Apakah petugas kesehatan Puskesmas Rawasari langsung } \\
\text { memeriksa kesehatan saudara saat melakukan konseling? }\end{array}$ & 24 & 96 & 32 & 96 & 18 & 36 & 3 & 3 & 231 \\
\hline 3 & $\begin{array}{l}\text { Apakah petugas kesehatan Puskesmas Rawasari menjelaskan } \\
\text { tentang mitos HIV sebelum melakukan konseling dan tes HIV? }\end{array}$ & 19 & 76 & 32 & 96 & 23 & 46 & 3 & 3 & 221 \\
\hline 4 & $\begin{array}{l}\text { Apakah petugas kesehatan Puskesmas Rawasari menganjurkan } \\
\text { saudara melakukan konseling dan tes HIV? }\end{array}$ & 19 & 76 & 31 & 93 & 23 & 46 & 4 & 4 & 219 \\
\hline 5 & $\begin{array}{l}\text { Apakah petugas kesehatan Puskesmas Rawasari menjelaskan } \\
\text { kapan melakukan konseling dan tes HIV kembali? }\end{array}$ & 16 & 64 & 33 & 99 & 24 & 48 & 4 & 4 & 215 \\
\hline 6 & $\begin{array}{l}\text { Apakah petugas kesehatan Puskesmas Rawasari memberikan } \\
\text { informasi bahwa konseling dan tes HIV penting dilakukan }\end{array}$ & 12 & 48 & 26 & 78 & 23 & 46 & 16 & 16 & 188 \\
\hline 7 & $\begin{array}{l}\text { Apakah petugas kesehatan Puskesmas Rawasari memberikan } \\
\text { informasi pada saudara dengan menggunakan bahasa yang mudah } \\
\text { dan dapat dimengerti? }\end{array}$ & 21 & 84 & 28 & 84 & 24 & 48 & 4 & 4 & 220 \\
\hline 8 & $\begin{array}{l}\text { Apakah petugas kesehatan Puskesmas Rawasari memberikan } \\
\text { pelayanan saat melakukan konseling dengan cepat? }\end{array}$ & 18 & 72 & 36 & 108 & 15 & 30 & 8 & 8 & 218 \\
\hline 9 & $\begin{array}{l}\text { Apakah petugas kesehatan Puskesmas Rawasari menyarankan agar } \\
\text { mengajak teman lain yang beresiko untuk melakukan konseling? }\end{array}$ & 21 & 84 & 34 & 102 & 15 & 30 & 7 & 7 & 223 \\
\hline 10 & $\begin{array}{l}\text { Apakah petugas kesehatan Puskesmas Rawasari memberitahukan } \\
\text { kalau di Puskesmas Rawasari ada klinik konseling dan tes HIV? }\end{array}$ & 18 & 72 & 32 & 96 & 25 & 50 & 2 & 2 & 220 \\
\hline 11 & $\begin{array}{l}\text { Apakah petugas kesehatan Puskesmas Rawasari menganjurkan } \\
\text { agar saudari mengajak pasangan saudari melakukan konseling dan } \\
\text { tes HIV? }\end{array}$ & 21 & 84 & 25 & 75 & 27 & 54 & 4 & 4 & 217 \\
\hline 12 & $\begin{array}{l}\text { Apakah petugas kesehatan Puskesmas Rawasari menjelaskan } \\
\text { tentang tahap-tahap konseling dan tes HIV? }\end{array}$ & 23 & 92 & 28 & 84 & 19 & 38 & 7 & 7 & 221 \\
\hline 13 & $\begin{array}{l}\text { Apakah petugas kesehatan Puskesmas Rawasari memberitahu } \\
\text { kapan melakukan konseling kembali setelah pemeriksaan pertama }\end{array}$ & 24 & 96 & 28 & 84 & 23 & 46 & 2 & 2 & 228 \\
\hline 14 & $\begin{array}{l}\text { Apakah petugas kesehatan Puskesmas Rawasari berada di klinik } \\
\text { VCT ketika saudari ingin melakukan konseling dan tes HIV }\end{array}$ & 23 & 92 & 34 & 102 & 16 & 32 & 4 & 4 & 230 \\
\hline
\end{tabular}

Berdasarkan tabel 10 dari 14 pernyataan, pernyataan responden yang menyatakan bahwa peran petugas kesehatan Puskesmas Rawasari yang rendah adalah memberikan informasi bahwa konseling dan tes HIV penting dilakukan yaitu nilai skor sebesar 188, menjelaskan kapan melakukan konseling dan tes HIV kembali yaitu nilai skor sebesar 215, dan menganjurkan agar mengajak pasangan melakukan konseling dan tes HIV yaitu nilai skor sebesar 217 .

Dari penghitungan jumlah jawaban maka peneliti dapat mengetahui berapa frekuensi responden yang memiliki peran petugas kesehatan yang kurang baik dan baik. Setelah dilakukan scoring 14 pernyataan pada variabel peran petugas kesehatan dengan nilai mean/median maka responden dengan peran petugas kesehatan kurang baik jika score atau nilai jawaban < median (40) dari nilai total, dan responden dengan peran petugas kesehatan baik jika skor atau nilai jawaban $\geq$ median (40) dari nilai total. Untuk lebih jelasnya dapat dilihat tabel berikut

\begin{tabular}{cccc}
$\begin{array}{c}\text { Tabel 11. Distribusi Responden Berdasarkan } \\
\text { Peran Petugas Kesehatan dengan Perilaku }\end{array}$ \\
\multicolumn{3}{c}{ Wanita Pekerja Seks Melakukan Konseling } \\
dan Tes HIV di Payo Sigadung Kota Jambi \\
\hline \multirow{2}{*}{ No } & $\begin{array}{c}\text { Peran Petugas } \\
\text { Kesehatan }\end{array}$ & Jumlah & $\begin{array}{c}\text { Persentase } \\
(\%)\end{array}$ \\
\hline 1. & Kurang baik & 38 & 49,4 \\
2. & Baik & 39 & 50,6 \\
& Jumlah & 77 & 100 \\
\hline
\end{tabular}


Berdasarkan tabel 11 dapat diketahui dari 77 responden, sebanyak $49,4 \%$ berpendapat peran petugas kesehatan yang kurang baik terhadap konseling dan tes HIV dan sebanyak 50,6\% responden berpendapat peran petugas kesehatan yang baik terhadap konseling dan tes HIV.

Tabel 12. Hubungan Pengetahuan dengan Perilaku Wanita Pekerja Seks Melakukan Konseling dan Tes HIV di Payo Sigadung Kota Jambi

\begin{tabular}{|c|c|c|c|c|c|c|c|}
\hline \multirow{3}{*}{ Pengetahuan } & \multicolumn{4}{|c|}{$\begin{array}{c}\text { Perilaku Wanita Pekerja Seks Melakukan } \\
\text { Konseling dan Tes H1V }\end{array}$} & \multicolumn{2}{|c|}{ Jumlah } & \multirow[t]{3}{*}{$\begin{array}{c}\text { P- } \\
\text { Value }\end{array}$} \\
\hline & \multicolumn{2}{|c|}{ Kurang baik } & & Baik & & & \\
\hline & $\mathrm{Jml}$ & $\%$ & $\mathrm{Jml}$ & $\%$ & $\mathrm{Jml}$ & $\%$ & \\
\hline Rendah & 36 & 81,8 & 8 & 18,2 & 44 & 100 & \multirow[t]{3}{*}{0,000} \\
\hline Tinggi & 11 & 33,3 & 22 & 66,7 & 33 & 100 & \\
\hline Jumlah & 47 & 61,0 & 30 & 30,0 & 77 & 100 & \\
\hline
\end{tabular}

Berdasarkan tabel 12 diketahui bahwa dari 77 responden terdapat 44 responden memiliki pengetahuan yang rendah sebanyak 36 responden $(81,8 \%)$ memiliki perilaku kurang baik dalam melakukan konseling dan tes HIV dan 8 responden $(18,2 \%)$ memiliki perilaku baik dalam melakukan konseling dan tes HIV, sedangkan 33 responden yang memiliki pengetahuan tinggi sebanyak 11 responden $(33,3 \%)$ memiliki perilaku kurang baik dalam melakukan konseling dan tes
HIV dan sebanyak 22 responden $(66,7 \%)$ memiliki perilaku baik dalam melakukan konseling dan tes HIV.

Berdasarkan nilai uji statistik hasil uji statistik yang diperoleh $p$-value $0,000(\alpha<0,05)$ yang berarti ada hubungan yang bermakna antara pengetahuan dengan perilaku wanita pekerja seks melakukan konseling dan tes HIV di Payo Sigadung Kota Jambi

Tabel 13. Hubungan Sikap dengan Perilaku Wanita Pekerja Seks Melakukan Konseling dan Tes HIV di Payo Sigadung Kota Jambi

\begin{tabular}{|c|c|c|c|c|c|c|c|}
\hline \multirow{3}{*}{ Sikap } & \multicolumn{4}{|c|}{$\begin{array}{c}\text { Perilaku Wanita Pekerja Seks Melakukan } \\
\text { Konseling dan Tes HIV }\end{array}$} & \multirow{2}{*}{\multicolumn{2}{|c|}{ Jumlah }} & \multirow[t]{3}{*}{$\begin{array}{c}\text { P- } \\
\text { Value }\end{array}$} \\
\hline & \multicolumn{2}{|c|}{ Kurang baik } & \multicolumn{2}{|c|}{ Baik } & & & \\
\hline & $\mathrm{Jml}$ & $\%$ & $\mathrm{Jml}$ & $\%$ & $\mathrm{Jml}$ & $\%$ & \\
\hline Kurang baik & 33 & 84,6 & 6 & 15,4 & 39 & 100 & 0,000 \\
\hline Baik & 14 & 36,8 & 24 & 63,2 & 42 & 100 & \\
\hline Jumlah & 47 & 61,0 & 30 & 30,0 & 77 & 100 & \\
\hline
\end{tabular}

Berdasarkan tabel 13 diketahui bahwa dari 77 responden, terdapat 39 responden memiliki sikap yang kurang baik sebanyak 33 responden $(84,6 \%)$ memiliki perilaku kurang baik dalam melakukan konseling dan tes HIV dan 6 responden $(15,4 \%)$ memiliki perilaku baik dalam melakukan konseling dan tes HIV, sedangkan 42 responden yang memiliki sikap yang baik sebanyak 14 responden $(36,8 \%)$ memiliki perilaku kurang baik dalam melakukan konseling dan tes
HIV dan sebanyak 24 responden $(63,2 \%)$ memiliki perilaku baik dalam melakukan konseling dan tes HIV.

Berdasarkan nilai uji statistik hasil uji statistik yang diperoleh $p$-value $0,000(\alpha<0,05)$ yang berarti ada hubungan yang bermakna antara sikap dengan perilaku wanita pekerja seks melakukan konseling dan tes HIV di Payosigadung Kota Jambi. 
Tabel 14. Hubungan Peran Petugas kesehatan dengan Perilaku Wanita Pekerja Seks Melakukan Konseling dan Tes HIV di Payo Sigadung Kota Jambi

\begin{tabular}{|c|c|c|c|c|c|c|c|}
\hline \multirow{3}{*}{$\begin{array}{l}\text { Peran Petugas } \\
\text { kesehatan }\end{array}$} & \multicolumn{4}{|c|}{$\begin{array}{l}\text { Perilaku Wanita Pekerja Seks Melakukan } \\
\text { Konseling dan Tes HIV }\end{array}$} & \multirow{2}{*}{\multicolumn{2}{|c|}{ Jumlah }} & \multirow[t]{3}{*}{$\begin{array}{c}\text { P- } \\
\text { Value }\end{array}$} \\
\hline & \multicolumn{2}{|c|}{ Kurang baik } & \multicolumn{2}{|c|}{ Baik } & & & \\
\hline & $\mathrm{Jml}$ & $\%$ & $\mathrm{Jml}$ & $\%$ & $\mathrm{Jml}$ & $\%$ & \\
\hline Kurang baik & 29 & 76,3 & 9 & 23,7 & 38 & 100 & 0,013 \\
\hline Baik & 18 & 46,2 & 21 & 53,8 & 39 & 100 & \\
\hline Jumlah & 47 & 61,0 & 30 & 30,0 & 77 & 100 & \\
\hline
\end{tabular}

Berdasarkan tabel 14 diketahui bahwa dari 77 responden, terdapat 38 responden berpendapat peran petugas kesehatan yang kurang baik sebanyak 29 responden $(76,3 \%)$ memiliki perilaku kurang baik dalam melakukan konseling dan tes HIV dan 9 responden $(23,7 \%)$ memiliki perilaku baik dalam melakukan konseling dan tes HIV, sedangkan 39 responden yang berpendapat peran petugas kesehatan sudah baik sebanyak 18 responden $(46,2 \%)$ memiliki perilaku kurang baik dalam melakukan konseling dan tes HIV dan sebanyak 21 responden $(53,8 \%)$ memiliki perilaku baik dalam melakukan konseling dan tes HIV.

Berdasarkan nilai uji statistik hasil uji statistik yang diperoleh $p$-value $0,013(\alpha<0,05)$ yang berarti ada hubungan yang bermakna antara peran petugas kesehatan dengan perilaku wanita pekerja seks melakukan konseling dan tes HIV di Payo Sigadung Kota Jambi.

\section{Hubungan Pengetahuan dengan Perilaku Wanita Pekerja Seks Melakukan Konseling dan Tes HIV di Payo Sigadung Kota Jambi}

Hasil penelitian menunjukkan bahwa dari

77 orang responden terdapat 44 responden memiliki pengetahuan yang rendah sebanyak 36 responden $(81,8 \%)$ memiliki perilaku kurang baik dalam melakukan konseling dan tes HIV dan 8 responden $(18,2 \%)$ memiliki perilaku baik dalam melakukan konseling dan tes HIV, sedangkan 33 responden yang mempunyai pengetahuan tinggi sebanyak 11 responden $(33,3 \%)$ memiliki perilaku kurang baik dalam melakukan konseling dan tes HIV dan sebanyak 22 responden $(66,7 \%)$ memiliki perilaku baik dalam melakukan konseling dan tes HIV.

Berdasarkan nilai uji statistik hasil uji statistik yang diperoleh p-value 0,000 $(\alpha<0,05)$ yang berarti ada hubungan yang bermakna antara pengetahuan dengan perilaku wanita pekerja seks melakukan konseling dan tes HIV di Payo Sigadung Kota Jambi.

Hasil penelitian menunjukkan bahwa pengetahuan wanita pekerja seks yang rendah lebih banyak yang tidak melakukan konseling dan tes HIV, sebaliknya wanita pekerja seks yang berpengetahuan tinggi lebih banyak melakukan konseling dan tes HIV. Keadaan tersebut memperlihatkan bahwa pengetahuan memegang peranan yang penting dalam melakukan konseling dan tes HIV, hal itu adalah sesuatu yang wajar karena mereka yang lebih tinggi pengetahuannya akan dapat mengerti manfaat melakukan konseling dan tes HIV. Hal ini dipegaruhi oleh ketersediaan sumber daya kesehatan, keterjangkauan sumberdaya kesehatan dan prioritas dan komitmen masyarakat/ pemerintah terhadap kesehatan, sehingga mereka tidak mendapatkan informasi tentang konseling dan tes HIV.

Hasil kuesioner terhadap pengetahuan responden menggambarkan bahwa dari 77 responden sebanyak 58 responden $(75,3 \%)$ tidak mengetahui tujuan kegiatan konseling bagi klien, sebanyak 46 responden $(59,7 \%)$ tidak mengetahui mengapa perlu melakukan konseling dan tes HIV dan sebanyak 45 responden $(58,4 \%)$ tidak mengetahui materi yang didapat saat konseling sebelum melakukan tes HIV.

Hasil penelitian ini sejalan dengan penelitian Mardyana (2009) diketahui bahwa pengetahuan yang cukup baik yaitu sebanyak 37 responden $(55,2 \%)$ dari 67 responden tentang konseling tes HIV dan pengetahuan yang rendah yaitu $42,85 \%$ dari seluruh responden yang ada di Resosialisasi Argorejo Kota Semarang, kesimpulan dari penelitian menunjukkan bahwa ada hubungan pengetahuan dengan konseling tes HIV.

Pengetahuan merupakan hasil dari tahu, dan ini terjadi setelah orang melakukan pengindraan terhadap sesuatu objek tertentu. 
Penginderaan terjadi melalui pancaindra manusia, yakni indra penglihatan, pendengaran, penciuman, rasa dan raba. Sebagian besar pengetahuan manusia diperoleh melalui mata dan telinga (Notoatmodjo, 2012).

Menurut WHO, strategi perubahan perilaku salah satunya memberi informasi atau edukasi. Upaya ini mengubah perilaku yang dilaksanakan dengan cara persuasi, bujukan, himbauan, ajakan, memberi informasi, dan memberi kesadaran melalui kegiatan yang disebut pendidikan kesehatan atau penyuluhan kesehatan. Upaya ini dilakukan untuk meningkatkan pengetahuan dan akan menimbulkan sikap dan akhirnya berperilaku yang didasarkan pada kesadaran dan kemauan individu yang bersangkutan (Maulana, 2013).

Sehubungan dengan hasil penelitian yang perlu ditingkatkan pengetahuan mengenai tahapan pelayanan konseling dan tes HIV, tujuan dan sasaran melakukan konseling dan tes HIV.

Menurut Depkes RI (2009) tahapan pelayanan konseling dan tes HIV terdiri dari : konseling pra tes HIV yaitu membantu klien menyiapkan diri untuk melakukan pemeriksaan darah atau tes HIV, tes HIV (pengambilan dan pemeriksaan darah), konseling pasca tes HIV yaitu membantu klien memahami dan menyesuaikan diri dengan hasil tes.

Menurut Nursalam \& Kurniawati (2011) konseling HIV/AIDS memiliki tujuan mencegah penularan HIV dengan cara mengubah perilaku. Untuk mengubah perilaku, ODHA (orang dengan HIV/AIDS) tidak hanya membutuhkan informasi belaka, tetapi yang jauh lebih penting adalah pemberian dukungan yang dapat menumbuhkan motivasi mereka, misalnya dalam perilaku seks aman, tidak berganti-ganti jarum suntik, dan lainlain.

Menurut Depkes RI (2009) sasaran konseling dan tes HIV antara lain masyarakat yang ingin mengetahui status HIV nya agar dapat mencegah dirinya dari penularan infeksi penyakit yang lain dan penularan kepada orang lain, masyarakat yang berisiko tertular HIV, karena perilaku risiko tinggi (berhubungan seks dengan berganti-ganti pasangan, penyalahgunaan narkoba).

Berdasarkan uraian diatas masih rendahnya pengetahuan wanita pekerja seks tentang perilaku melakukan konseling dan tes HIV karena masih kurangnya sosialisasi dari petugas kesehatan. Peneliti menyarankan kepada Dinas Kesehatan Kota Jambi dan Puskesmas Rawasari untuk meningkatkan pengetahuan wanita pekerja seks di Payo Sigadung Kota Jambi dengan meningkatkan penyuluhan langsung secara berkala maupun tidak langsung melalui media informasi seperti leaflet dan poster mengenai tahapan pelayanan konseling dan tes HIV, tujuan dan sasaran agar wanita pekerja seks mendapatkan pengetahuan tentang konseling dan tes HIV.

\section{Hubungan Sikap dengan Perilaku Wanita Pekerja Seks Melakukan Konseling dan Tes HIV di Payo Sigadung Kota Jambi}

Hasil penelitian menunjukkan bahwa dari 77 responden, terdapat 39 responden memiliki sikap yang kurang baik sebanyak 33 responden $(84,6 \%)$ memiliki perilaku kurang baik dalam melakukan konseling dan tes HIV dan 6 responden $(15,4 \%)$ memiliki perilaku baik dalam melakukan konseling dan tes HIV, sedangkan 42 responden yang mempunyai sikap yang baik sebanyak 14 responden $(36,8 \%)$ memiliki perilaku kurang baik dalam melakukan konseling dan tes HIV dan sebanyak 24 responden $(63,2 \%)$ memiliki perilaku baik dalam melakukan konseling dan tes HIV.

Berdasarkan nilai uji statistik hasil uji statistik yang diperoleh $p$-value $0,000(\alpha<0,05)$ yang berarti ada hubungan yang bermakna antara sikap dengan perilaku wanita pekerja seks melakukan konseling dan tes HIV di Payo Sigadung.

Hasil penelitian menunjukkan bahwa wanita pekerja seks yang memiliki sikap yang kurang baik lebih banyak yang tidak melakukan konseling dan tes HIV, sebaliknya wanita pekerja seks yang memiliki sikap yang baik lebih banyak yang melakukan konseling dan tes HIV. Keadaan tersebut memperlihatkan bahwa sikap juga memegang peranan yang penting dalam melakukan konseling dan tes HIV, hal itu adalah sesuatu yang wajar karena mereka yang memiliki sikap yang baik akan melakukan konseling dan tes HIV.

Hasil kuesioner terhadap sikap responden tentang konseling dan tes HIV adalah pernyataan dengan nilai rendah adalah yang menyatakan tidak perlu mengetahui hal-hal yang berkaitan dengan HIV dan AIDS karena merasa tidak memiliki 
perilaku yang berisiko tertular HIV dan AIDS, tidak perlu melakukan konseling dan tes HIV karena belum ada gejala AIDS, dan tidak mau melakukan konseling dan tes HIV takut ketahuan penyakit.

Hasil penelitian ini sejalan dengan penelitian yang dilakukan oleh Arisman (2009) didapatkan kesimpulan bahwa faktor tingkat pengetahuan pekerja seks komersial, sikap, dan peran petugas kesehatan merupakan faktor utama yang menyebabkan kurangnya peran mandiri terhadap konseling tes HIV.

$$
\text { Menurut Notoatmodjo }
$$

menyebutkan bahwa sikap merupakan reaksi atau respons yang masih tertutup dari seseorang terhadap stimulus atau objek. Setelah seseorang mengetahui stimulus atau objek, proses selanjutnya akan menilai atau bersikap terhadap stimulus atau objek kesehatan tersebut. Oleh sebab itu indikator untuk sikap kesehatan yaitu sikap terhadap sakit dan penyakit bagaimana penilaian atau pendapat terhadap gejala atau tanda-tanda penyakit, penyebab penyakit, cara penularan penyakit, cara pencegahan dan sebagainya. Sikap cara pemeliharaan dan cara hidup sehat adalah penilaian atau pendapat seseorang terhadap caracara memelihara dan cara-cara(berperilaku) hidup sehat.

Tertular HIV (atau menjadi HIV-positif) bukan berarti kita langsung jatuh sakit. Seseorang bisa hidup dengan HIV didalam tubuhnya bertahun-tahun lamanya tanpa merasa sakit atau mengalami gangguan kesehatan yang serius. Lamanya masa sehat ini sangat dipengaruhi oleh keinginan yang kuat dari diri kita sendiri dan bagaimana kita menjaga kesehatan dengan pola hidup yang sehat (Yayasan Spiritia, 2009).

Berdasarkan uraian diatas sikap wanita pekerja seks yang kurang baik terhadap perilaku melakukan konseling dan tes HIV disebabkan oleh merasa tidak memiliki perilaku yang berisiko tertular HIV dan AIDS, belum ada gejala AIDS dan takut ketahuan penyakit. Untuk itu diharapkan agar petugas kesehatan Puskesmas Rawasari mampu meningkatkan pemahaman kepada wanita pekerja seks tentang konseling dan tes HIV bahwa pemeriksaan HIV itu penting dilakukan karena HIV tidak dapat dinilai hanya dengan melihat saja melainkan melalui pemeriksaan HIV dan hal-hal yang berkaitan dengan penularan dan pencegahan HIV/AIDS.
Petugas kesehatan juga mengajak dan mendorong agar wanita pekerja seks mau melakukan konseling dan tes HIV.

\section{Hubungan Peran Petugas kesehatan dengan Perilaku Wanita Pekerja Seks Melakukan Konseling dan Tes HIV di Payo Sigadung Kota Jambi}

Hasil penelitian menunjukkan bahwa dari 77 responden, terdapat 38 responden berpendapat peran petugas kesehatan yang kurang baik sebanyak 29 responden $(76,3 \%)$ memiliki perilaku kurang baik dalam melakukan konseling dan tes HIV dan 9 responden $(23,7 \%)$ memiliki perilaku baik dalam melakukan konseling dan tes HIV, sedangkan 39 responden yang berpendapat peran petugas kesehatan sudah baik sebanyak 18 responden $(46,2 \%)$ memiliki perilaku kurang baik dalam melakukan konseling dan tes HIV dan sebanyak 21 responden $(53,8 \%)$ memiliki perilaku baik dalam melakukan konseling dan tes HIV.

Berdasarkan nilai uji statistik hasil uji statistik yang diperoleh $p$-value $0,013(\alpha<0,05)$ yang berarti ada hubungan yang bermakna antara peran petugas kesehatan dengan perilaku wanita pekerja seks melakukan konseling dan tes HIV di Payo Sigadung Kota Jambi Tahun 2014.

Hasil penelitian ini sejalan dengan penelitian yang dilakukan oleh Arisman (2009) didapatkan kesimpulan bahwa faktor tingkat pengetahuan pekerja seks komersial, sikap dan peran petugas kesehatan merupakan faktor utama yang menyebabkan kurangnya peran mandiri terhadap konseling dan tes HIV.

Hasil penelitian menunjukkan bahwa wanita pekerja seks yang memiliki berpendapat kurang baik terhadap peran petugas kesehatan lebih banyak yang tidak melakukan konseling dan tes HIV, sebaliknya wanita pekerja seks berpendapat bahwa peran petugas kesehatan baik lebih banyak yang melakukan konseling dan tes HIV. Keadaan tersebut memperlihatkan bahwa sikap juga memegang peranan yang penting dalam melakukan konseling dan tes HIV, hal itu adalah sesuatu yang wajar karena mereka yang memiliki sikap yang baik akan melakukan konseling dan tes HIV.

Hasil kuesioner terhadap responden tentang peran petugas kesehatan mengenai konseling dan tes HIV dengan nilai rendah adalah 
yang menyatakan bahwa petugas kesehatan Puskesmas Rawasari tidak memberikan informasi, tidak menjelaskan waktu melakukan konseling dan tes HIV kembali dan tidak menganjurkan agar mengajak pasangan melakukan konseling dan tes HIV.

Akibat pekerjaannya, seorang pekerja seks sangat beresiko terkena penyakit menular melalui hubungan seks, termasuk HIV/AIDS, dibanding perempuan-perempuan lain. Bila ia sudah terkena gonorhea, chlamydia, herpes, atau sifilis resiko tertular HIV makin besar. Terutama bagi pekerja seks yang masih remaja. Virus HIV dengan mudah menyelinap masuk lewat luka di vagina, padahal organ seksual remaja belum berkembang sepenuhnya sehingga gampang terluka saat berhubungan seks. Banyak pekerja seks tidak mendapat informasi yang memadai tentang semua risiko diatas, lebih-lebih tentang cara pencegahan dan penanggulangannya. Lantaran prasangka masyarakat, mereka tersisih dan terkucil, tidak dianggap sebagai anggota masyarakat yang memiliki hak atas informasi demi menjaga kesehatan. Bahkan banyak pekerja seks yang tidak dilayani, atau dilayani sembarangan saja, bila berobat ke Puskesmas atau dokter (Burns et. al, 2005).

Salah satu peran perawat sebagai pendidik dalam keperawatan. Perawat berperan dalam mendidik individu, keluarga, kelompok dan masyarakat serta tenaga kesehatan yang berada dibawah tanggung jawabnya. Peran ini berupa penyuluhan pada klien, maupun bentuk desiminasi ilmu kepada peserta didik keperawatan (Potter\&Perry, 2005).

Dengan adanya peran yang baik dari petugas kesehatan, seperti penyuluhan-penyuluhan yang teratur dan berkesinambungan tentunya akan meningkatkan perlaku wanita pekerja seks melakukan konseling dan tes HIV. Untuk itu diharapkan agar petugas kesehatan melakukan penyuluhan kepada wanita pekerja seks bahwa konseling dan tes HIV penting dilakukan.

\section{SIMPULAN}

Berdasarkan hasil penelitian dapat disimpulkan dari 77 responden, 61\% memiliki perilaku kurang baik melakukan konseling tes HIV dan 39\% memiliki perilaku baik melakukan konseling tes HIV, 57,1\% responden mempunyai pengetahuan yang rendah, 50,6\% mempunyai sikap yang kurang baik, 50,6\% responden berpendapat peran petugas kesehatan yang baik terhadap konseling dan tes HIV. Ada hubungan yang bermakna antara pengetahuan, sikap dan peran petugas kesehatan dengan perilaku wanita pekerja seks melakukan konseling dan tes HIV di Payo Sigadung Kota Jambi. Disarankan untuk meningkatan penyebaran informasi kepada masyarakat khususnya wanita pekerja seks bahwa konseling dan tes HIV penting dilakukan melalui media massa seperti TV, radio, surat kabar, baliho dan lain-lain, agar petugas kesehatan Puskesmas Rawasari meningkatkan penyuluhan langsung secara berkala maupun tidak langsung melalui media informasi seperti leaflet dan poster mengenai tahapan pelayanan konseling dan tes HIV, tujuan dan sasaran agar wanita pekerja seks mendapatkan pengetahuan tentang konseling dan tes HIV.

\section{DAFTAR PUSTAKA}

Arisman,2009.Faktor-faktor yang menyebabkan kurangnya peran mandiri wanita pekerja seks komersial terhadap konseling dan tes HIV di Desa SidoMukti Kabupaten Bantul.

BKKBN,2007. Informasi tentang manfaat KB dan kaitannya terhadap kesehatan ibu dan anak.

Burns, et. al, 2005. Bila perempuan tidak ada dokter: panduan kesehatan dan pengobatan bagi perempuan. (Sandy Nieman, penerjemah). Yogyakarta: INSIS Press.

Departemen Kesehatan RI. Ditjen PP\&PL, 2006.Pedoman penatalaksanaan infeksi menular seksual.

,2009 Konseling dan tes HIV sukarela(voluntary counseling and testing).

Dinas Kesehatan Provinsi Jambi, 2013.Laporan perkembangan situasi HIV/AIDS menurut Kab/Kota di Provinsi Jambi tahun 20112013

Efendi, 2008. Konseling penyakit menular seksual dan HIV/AIDS untuk tenaga kesehatan. Jakarta:HAPP/USAID.

Green, et al, 1980.Perencanaan pendidikan kesehatan sebuah pendekatan diagnosis. (Zulazmi Hamdy., Zarfiel Tafal., Sudarti Kresno, penerjemah).

Hidayat,2009.Metode penelitian keperawatan dan teknik analisis data.Jakarta:SalembaMedika. 
KPA, 2011.Panduan pelaksanaan peringatan hari AIDS sedunia 2011.

Kementerian Kesehatan RI,2011. Pedoman konseling dan tes HIV. ,2012.Modul teknis layanan konprehensif HIV-IMS berkesinambungan.

Kumalasari\&Andhyantoro, 2012.Kesehatan reproduksiuntuk mahasiswa kebidanan dan keperawatan. Jakarta: SalembaMedika.

Klinik IMS"Mitra Berseri” Puskesmas Rawasari Kota Jambi, 2013 .Angka kunjungan wanita pekerja seks.

Mardyana, 2009. Hubungan pengetahuan dengan konseling dan tes HIV di Resosialisasi Argorejo Kota Semarang.

Maulana,2013.Promosi kesehatan. Jakarta:EGC

Notoatmodjo, 2007. Promosi kesehatan \& ilmu perilaku. Jakarta: PT. Rineka Cipta. ,2010. Ilmu perilaku kesehatan. Jakarta: PT. Rineka Cipta. ,2010.Metodologi penelitian kesehatan.Jakarta: PT. Rineka Cipta. ,2012. Promosi kesehatan dan perilaku kesehatan. Jakarta: PT. Rineka Cipta.

Nursalam\& Kurniawati,2011.Asuhan Keperawatan Pada Pasien Terinfeksi Jakarta: PT. Salemba Medika.

Potter \& Perry, 2005.Fundamental keperawatan, konsep, proses, danpraktik, edisi 4 volume 2. Jakarta: EGC.

Puskesmas Rawasari, Profil puskesmas rawasari tahun 2012.

Sekolah Tinggi Ilmu Kesehatan Harapan Ibu Jambi, 2012. Pedoman penyusunan skripsi program studi kesehatan masyarakat.

Soedarto,2009. Penyakit menular di Indonesia. Jakarta: CV. Sagung Seto.

Wawan \& Dewi,2010.Teori \& Pengukuran Pengetahuan, Sikap dan Perilaku Manusia, Yogyakarta: NuhaMedika.

Widoyono, 2011.Penyakit tropis epidemiologi, penularan, pencegahan dan pemberantasannya. Jakarta: PT. Erlangga.

Yayasan Spiritia, 2009. Pasien berdaya. Jakarta: Pelangi Grafika Rancang Medika. 